\title{
Urban Ecosystem Services: New Findings for Landscape Architects, Urban Planners, and Policymakers
}

\author{
Alessio Russo $^{1, *(\mathbb{D}) \text { and Giuseppe T. Cirella }}{ }^{2}$ (D) \\ 1 School of Arts, University of Gloucestershire, Cheltenham GL50 4AZ, UK \\ 2 Faculty of Economics, University of Gdansk, 81-824 Sopot, Poland; gt.cirella@ug.edu.pl \\ * Correspondence: arusso@glos.ac.uk; Tel.: +44-(0)1242-714557
}

check for updates

Citation: Russo, A.; Cirella, G.T. Urban Ecosystem Services: New Findings for Landscape Architects, Urban Planners, and Policymakers. Land 2021, 10, 88. https:// doi.org/10.3390/land10010088

Received: 11 January 2021

Accepted: 15 January 2021

Published: 19 January 2021

Publisher's Note: MDPI stays neutral with regard to jurisdictional claims in published maps and institutional affiliations.

Copyright: (c) 2021 by the authors. Licensee MDPI, Basel, Switzerland. This article is an open access article distributed under the terms and conditions of the Creative Commons Attribution (CC BY) license (https:// creativecommons.org/licenses/by/ $4.0 /)$.
More than half of the world's population lives in urban ecosystems. The United Nations has projected that $28 \%$ of people worldwide will be concentrated in cities with at least 1 million inhabitants by 2030 [1]. Worldwide megacities are projected to rise from 33 in 2018 to 43 in 2030 [1]. Urbanisation has a profound impact on how we as human beings interact with the world around us [2]. Cities are often described as new ecosystems that did not have a natural analogue before the expansion of the urban population [3]. Cities themselves are microcosms of the kinds of modifications that are occurring, making them informative test cases for understanding the dynamics of the socioecological system and response to change [4]. The concept of urban ecosystems has been defined as "those in which people live at high densities, and where built structures and infrastructure cover much of the land surface" [5]. However, the ecological interpretation of urban systems must also include less densely populated areas due to reciprocal flows and influences between densely and sporadically populated areas [5]. Research of urban ecosystems is a relatively new topic in ecology that dates back to the mid-1970s [6,7]. This concept is discussed across a wide range of science fields, including urban ecology, landscape ecology, environmental science, ecosystem services science, and public health [8]. The concept is also increasingly addressed in sustainability science, landscape architecture, architecture, engineering, urban design, and urban planning [8].

Nature in cities plays a vital role in urbanised systems as the ecological basis for human-nature relations and the production of urban ecosystem services [9]. Several early landscape architects, particularly Fredrick Law Olmsted (1822-1903), attempted not only to improve the aesthetic of the city but also to improve health and provide the crowded urban population with areas for rest and recreation [9]. Olmsted became a leading landscape architect, park builder, and advocate of the 19th century based on an intuitive understanding of the connection between nature and human wellbeing that underpins what we know today as ecosystem services [10]. Researchers define "urban ecosystem services" as "the benefits urban residents derive from local and regional ecosystem functions" that "are co-produced by people and ecosystems" [8,11-13]. Recently, Tan et al. (2020) examined the terminological grouping of "urban ecosystem services" over the past two decades. Two different-but equally valid-interpretations were disseminated: (1) from analogues of natural and seminatural ecosystems within urban boundaries and (2) a much broader definition that incorporates the former as well as urban city-based services [14].

Landscape architects and urban planners recognise urban ecosystem service as a powerful concept that guides the development of urban landscapes towards greater sustainability, resilience, and liveability [14]. It is also evident that urban ecosystem services contribute to the quality of urban life, even though urban citizens still rely on global ecosystem services to survive [15]. The UN Agenda 2030 clearly considers the role of ecosystem services in urban settings [16]. SDG (Sustainable Development Goal) 15 targets the conservation and restoration of using terrestrial ecosystems, reducing the loss of natural habitats and biodiversity, which play an important part in our common future and heritage. 
Cities, in particular, need to become "more inclusive, safe, resilient and sustainable", as stated in the title of SDG 11 [17], if they are to become "greener" and supportive of current mass urbanisation. Partial solutions to this phenomenon will be the widespread use of urban green technologies via ecosystem service-based features [16].

A number of studies demonstrate linkages between urban ecosystems and public health through a range of benefits such as the mitigation of heat hazards, improvement of mental health and wellbeing through contact with nature, and stormwater management. $[18,19]$. In particular, green and blue infrastructures provide several ecosystem services, such as pollution removal, carbon storage and sequestration, food production, noise reduction, and recreational and cultural values $[15,20,21]$ (Figure 1).

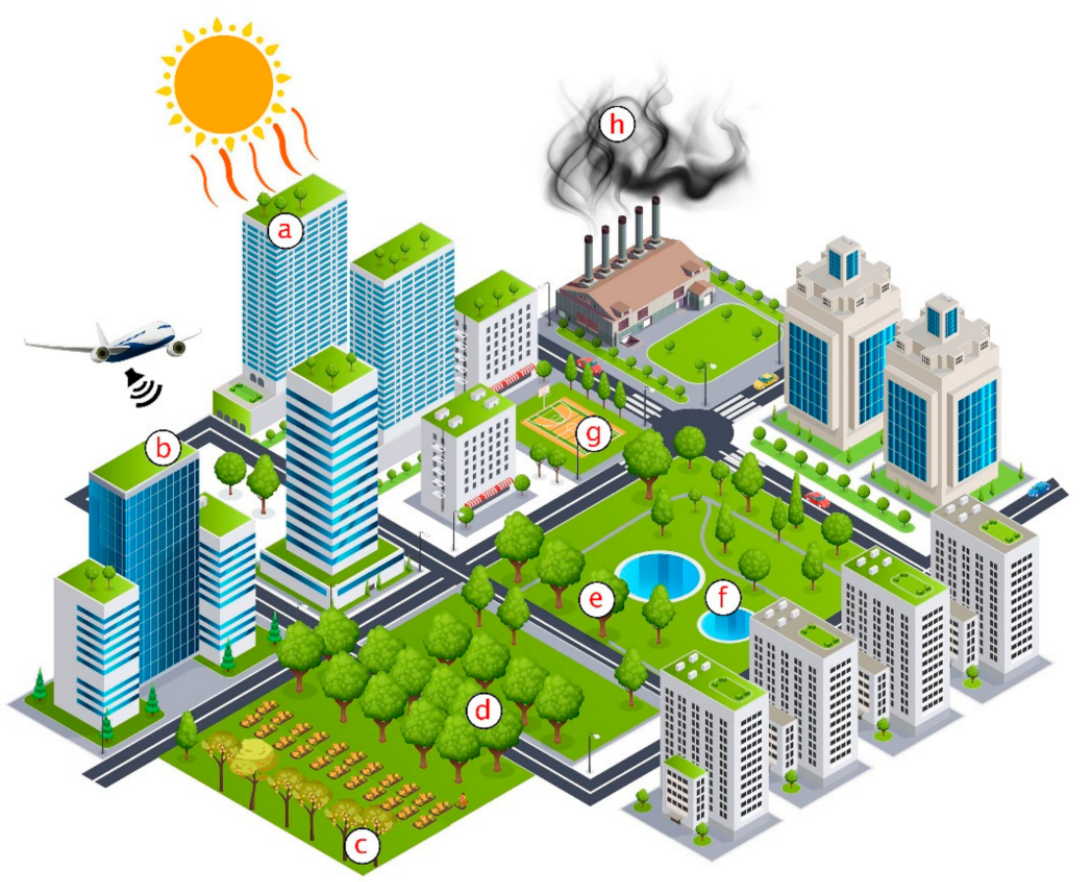

Figure 1. Ecosystem services provided by green and blue infrastructure: (a) regulation of microclimate, (b) noise reduction, (c) food production, (d) carbon storage and sequestration, (e) habitat provision, (f) run-off retention and water filtration, (g) recreational and cultural values, and (h) air purification (image modified from Macrovector/Freepik).

However, changes in ecological conditions resulting from human actions in urban environments ultimately impact human health and wellbeing [22]. Sustainability needs complete understanding at all levels of direct and indirect human interventions affecting ecological processes and ecosystem states [23]. According to Gómez-Baggethun and Barton [24], "urban ecosystems are still an open frontier in ecosystem service research", and the interface between economic costs and sociocultural impacts must be taken into account to "enhance resilience and quality of life in cities".

This Special Issue contains 12 peer-reviewed papers. The contributions are written by authors from several countries, including Australia, Chile, Ireland, Italy, Norway, Pakistan, Poland, South Africa, Sweden, the Netherlands, the United Kingdom, and the United States.

Brzoska and Spāge [25] reviewed urban ecosystem services of different types of green infrastructure. The review identified 40 different ecosystem service classes assessed in relation to different types of green infrastructure. The results show that the majority of the studies focused on assessing regulation ecosystem services classes such as filtration, sequestration, storage, and accumulation by "microorganisms, algae, plants, and animals" and "regulation of temperature and humidity, including ventilation and transpiration" in "urban green spaces" at the city dimension [25]. The results also show that the num- 
ber of assessments of provisioning ecosystem services has been increasing over the last 6 years. Only a few studies have considered individual small structures, such as green roofs or single gardens; moreover, green spaces are often aggregated into one object of investigation, mostly city-wide, leading to oversimplifications [25]. Colding et al. [26] focused on the incremental change in green spaces-a fate that is largely undetectable for urban residents. The research illustrates the set of drivers resulting in the subtle loss of urban green space and elaborates on the consequences of this for the resilience planning of ecosystem services [26]. Semeraro et al. [27] analysed a case study in Lecce, Italy, applying a top-down and bottom-up approach to dispute resolution at the institutional level in the use of urban space. The research suggests that in the socioecological system, the bottom institutional level can introduce innovation or a new vision in the use of free urban space, and, as a result, bottom-up participation can stimulate or trigger the evolution of the urban ecosystem, while the top institutional level drives a change from top-down to bottom-up participation information in planning actions between decision-makers [27].

Giliani et al. [28] studied the dynamics of urban landscape ecology in the Islamabad Capital Territory in Pakistan during the period of 1976-2016 [28]. The outcomes of their study show a consistent increase in the settlement class, with the highest annual rate of $8.79 \%$ during the period of $2000-2010$. Tree cover $>40 \%$ and $<40 \%$ canopies decreased at annual rates of $0.81 \%$ and $0.77 \%$, respectively, between 1976 and 2016. Forest fragmentation analysis indicates that core forests of $>500$ acres decreased from 392 (i.e., $65.41 \%$ ) to $241 \mathrm{~km}^{2}$ (i.e., $55 \%$ ) and patch forest increased from 15 (i.e., $2.46 \%$ ) to $20 \mathrm{~km}^{2}$ (i.e., $4.54 \%$ ) from 1976 to 2016. SDG indicator 11.3.1 land consumption rate to the population growth rate ratio was 0.62 from 1976 to 2000, increasing to 1.36 from 2000 to 2016 [28].

Holloway and Field [29] composed richness and abundance data for 771 quadrats across three counties, finding a total of 81 species, with 48 species on the groynes and 71 species on the natural rocky shores. Their research found similar degrees across structures for algae, higher diversity and abundance for lichens and mobile animals on natural shores, and higher numbers of sessile animals on groynes. The study points out that groynes host similar ecological communities to those found on natural shores, in which differences do exist, particularly with respect to rock-pool habitats [29].

Combrinck et al. [30] investigated the property values and distance to urban green space in Potchefstroom, South Africa. Potchefstroom residents recognise the social, environmental, and economic value of green spaces; however, fewer residents recognise the economic value of green spaces. Over half of the respondents agreed that green spaces are perceived as crime hotspots and thus as contributing to unsafe neighbourhoods and indicating a related ecosystem disservice. Approximately $60 \%$ of those surveyed agreed that they would pay more for a property that is located next to a green space.

Professional planners that had been surveyed agreed that unattractive green spaces are due to a lack of maintenance by local authorities and a lack of community engagement. Half of the planners involved in the survey stated that environmental considerations are not prioritised in the planning process, even though environmental management is considered a critical component of local urban planning approaches, policy, and legislative frameworks [30]. Parker and Simpson [31] developed a theoretical framework to support human-nature connections and urban resilience via green infrastructure. In particular, they explored how urban resilience theory and human-nature connection theory can inform urban development. The urban resilience theory advocates the improvement of policy and planning frameworks, risk reduction techniques, adaptation strategies, disaster recovery mechanisms, environmentally sustainable alternatives to fossil fuel energy, the building of social capital, and integration of ecologically sustainable urban green infrastructure [31].

In Sweden, to identify key factors for fostering the incorporation of ecosystem services into municipal planning practise, Khoshkar et al. [32] examined and evaluated the views and experiences of practitioners of local spatial planning practises in municipalities in Stockholm County [32]. The practitioners stressed the need to establish legal support and ecosystem services regulation at Swedish and EU policy levels. Moreover, focus was placed 
on the need for local capacity building and awareness of ecosystem services as well as increased regional support for enhancing local information sharing and learning. In order to fully integrate ecosystem services in urban planning for sustainable development in a decentralised local government structure, such as in Sweden, locally adapted practical tools and monitoring procedures were considered important [32].

In Poland, Rędzińska and Piotrkowska [33] developed a procedure of building neighbourhood resilience to climate threats, embedded in the planning and design process, and focused on the use of natural adaptive potential. This procedure was applied at the strategic level to the city of Warsaw by drawing up the ranking of districts with a view to prioritising adaptation measures based on climate threats, demographic vulnerability, and the assessment of the potential of Warsaw's green infrastructure [33]. In Oregon, Elderbrock et al. [34] developed a clear method for deciding between alternatives to green infrastructure based on their quantitative and qualitative potential to provide high-priority urban ecosystem services to different stakeholders in a specific area. They used and evaluated this method in Eugene by investigating the potential for increased urban ecosystem services resulting from the conversion of public grass to alternative planting regimes that align with expressed stakeholder priorities [34]. In Norway, Venvik and Boogaard [35] tested the hydraulic infiltration capacity of a rain garden. This research leads to an understanding of the dynamics of infiltration systems, including how a rain garden interacts with the hydrological and hydrogeological aspects of the local urban water cycle [35]. Finally, the contribution from Restemeyer and Boogaard [36] explored how online citizen science platforms, demonstrated by the case of ClimateScan, can stimulate stakeholder participation and encourage nature-based solutions. This has culminated in an illustrated map of over 5000 nature-based solutions initiatives around the world and an average of more than 100 visitors a day within 6 years [36].

As cities are expected to grow rapidly in the coming decades, it is important that urban ecosystem services are understood and valued by city planners and policymakers [15]. We do hope that the results of this Special Issue can be used by landscape architects, urban planners, and policymakers to make cities sustainable, safer, resilient, and adaptable to climate change and other future risks. The survival and wellbeing of the human species in urban environments depend on how we manage to provide ecosystem services for future generations.

Author Contributions: Writing—original draft preparation, A.R.; writing—review and editing, A.R. and G.T.C.; visualization, A.R. All authors have read and agreed to the published version of the manuscript.

Funding: This research received no external funding.

Acknowledgments: We are grateful to the MDPI Land team of academic editors and reviewers for assisting with the Special Issue's academic excellence. Vector imaging was designed by Macrovector/Freepik.

Conflicts of Interest: The authors declare no conflict of interest.

\section{References}

1. United Nations. The World 's Cities in 2018: Data booklet; United Nations: New York, NY, USA, 2018; p. 29.

2. Russo, A.; Cirella, G.T. Urban Sustainability: Integrating Ecology in City Design and Planning. In Sustainable Human-Nature Relations: Environmental Scholarship, Economic Evaluation, Urban Strategies; Cirella, G.T., Ed.; Springer Singapore: Singapore, 2020; pp. 187-204. ISBN 978-981-15-3049-4.

3. Pataki, D.E. Grand challenges in urban ecology. Front. Ecol. Evol. 2015, 3. [CrossRef]

4. Grimm, N.B.; Faeth, S.H.; Golubiewski, N.E.; Redman, C.L.; Wu, J.; Bai, X.; Briggs, J.M. Global change and the ecology of cities. Science 2008, 319, 756-760. [CrossRef] [PubMed]

5. Pickett, S.T.A.; Cadenasso, M.L.; Grove, J.M.; Nilon, C.H.; Pouyat, R.V.; Zipperer, W.C.; Costanza, R. Urban Ecological Systems: Linking Terrestrial Ecological, Physical, and Socioeconomic Components of Metropolitan Areas. Annu. Rev. Ecol. Syst. 2001, 32, 127-157. [CrossRef]

6. Pickett, S.T.A.; Grove, J.M. Urban ecosystems: What would Tansley do? Urban Ecosyst. 2009, 12, 1-8. [CrossRef]

7. Stearns, F. Urban Ecology Today. Science 1970, 170, 1006-1007. [CrossRef] [PubMed] 
8. Isaac, B.T. Cities and the Environment (CATE) Managing Cities as Urban Ecosystems: Fundamentals and a Framework for Los Angeles, California Managing Cities as Urban Ecosystems: Fundamentals and a Framework for Los Angeles, California. Cities Environ. 2017, 10, 1-30.

9. McPhearson, T.; Hamstead, Z.A.; Kremer, P. Urban Ecosystem Services for Resilience Planning and Management in New York City. Ambio 2014, 43, 502-515. [CrossRef]

10. Eisenman, T.S. Frederick Law Olmsted, Green Infrastructure, and the Evolving City. J. Plan. Hist. 2013, 12, 287-311. [CrossRef]

11. McPhearson, T.; Pickett, S.T.A.; Grimm, N.B.; Niemelä, J.; Alberti, M.; Elmqvist, T.; Weber, C.; Haase, D.; Breuste, J.; Qureshi, S. Advancing Urban Ecology toward a Science of Cities. Bioscience 2016, 66, 198-212. [CrossRef]

12. Larondelle, N.; Hamstead, Z.A.; Kremer, P.; Haase, D.; McPhearson, T. Applying a novel urban structure classification to compare the relationships of urban structure and surface temperature in Berlin and New York City. Appl. Geogr. 2014, 53, 427-437. [CrossRef]

13. Andersson, E.; McPhearson, T.; Kremer, P.; Gomez-Baggethun, E.; Haase, D.; Tuvendal, M.; Wurster, D. Scale and context dependence of ecosystem service providing units. Ecosyst. Serv. 2015, 12, 157-164. [CrossRef]

14. Tan, P.Y.; Zhang, J.; Masoudi, M.; Alemu, J.B.; Edwards, P.J.; Grêt-Regamey, A.; Richards, D.R.; Saunders, J.; Song, X.P.; Wong, L.W. A conceptual framework to untangle the concept of urban ecosystem services. Landsc. Urban Plan. 2020, 200, 103837. [CrossRef] [PubMed]

15. Bolund, P.; Hunhammar, S. Ecosystem services in urban areas. Ecol. Econ. 1999, 29, 293-301. [CrossRef]

16. Filho, W.L.; Barbir, J.; Sima, M.; Kalbus, A.; Nagy, G.J.; Paletta, A.; Villamizar, A.; Martinez, R.; Azeiteiro, U.M.; Pereira, M.J.; et al. Reviewing the role of ecosystems services in the sustainability of the urban environment: A multi-country analysis. J. Clean. Prod. 2020, 262, 121338. [CrossRef]

17. United Nations. The Sustainable Development Goals Report 2017; United Nations: New York, NY, USA, 2017.

18. Jennings, V.; Floyd, M.F.; Shanahan, D.; Coutts, C.; Sinykin, A. Emerging issues in urban ecology: Implications for research, social justice, human health, and well-being. Popul. Environ. 2017, 39, 69-86. [CrossRef]

19. Andreucci, M.B.; Russo, A.; Olszewska-Guizzo, A. Designing Urban Green Blue Infrastructure for Mental Health and Elderly Wellbeing. Sustainability 2019, 11, 6425. [CrossRef]

20. Russo, A.; Escobedo, F.J.; Timilsina, N.; Zerbe, S. Transportation carbon dioxide emission offsets by public urban trees: A case study in Bolzano, Italy. Urban For. Urban Green. 2015, 14, 398-403. [CrossRef]

21. Russo, A.; Cirella, G.T. Edible urbanism 5.0. Palgrave Commun. 2019, 5, 163. [CrossRef]

22. Alberti, M. The Effects of Urban Patterns on Ecosystem Function. Int. Reg. Sci. Rev. 2005, 28, 168-192. [CrossRef]

23. Douglas, I. Urban ecology and urban ecosystems: Understanding the links to human health and well-being. Curr. Opin. Environ. Sustain. 2012, 4, 385-392. [CrossRef]

24. Gómez-Baggethun, E.; Barton, D.N. Classifying and valuing ecosystem services for urban planning. Ecol. Econ. 2013, 86, 235-245. [CrossRef]

25. Brzoska, P.; Spāgé, A. From City-to Site-Dimension: Assessing the Urban Ecosystem Services of Different Types of Green Infrastructure. Land 2020, 9, 150. [CrossRef]

26. Colding, J.; Gren, A.; Barthel, S. The Incremental Demise of Urban Green Spaces. Land 2020, 9, 162. [CrossRef]

27. Semeraro, T.; Nicola, Z.; Lara, A.; Sergi Cucinelli, F.; Aretano, R. A Bottom-Up and Top-Down Participatory Approach to Planning and Designing Local Urban Development: Evidence from an Urban University Center. Land 2020, 9, 98. [CrossRef]

28. Gilani, H.; Ahmad, S.; Qazi, W.A.; Abubakar, S.M.; Khalid, M. Monitoring of Urban Landscape Ecology Dynamics of Islamabad Capital Territory (ICT), Pakistan, Over Four Decades (1976-2016). Land 2020, 9, 123. [CrossRef]

29. Holloway, P.; Field, R. Can Rock-Rubble Groynes Support Similar Intertidal Ecological Communities to Natural Rocky Shores? Land 2020, 9, 131. [CrossRef]

30. Combrinck, Z.; Cilliers, E.J.; Lategan, L.; Cilliers, S. Revisiting the Proximity Principle with Stakeholder Input: Investigating Property Values and Distance to Urban Green Space in Potchefstroom. Land 2020, 9, 235. [CrossRef]

31. Parker, J.; Simpson, G.D. A Theoretical Framework for Bolstering Human-Nature Connections and Urban Resilience via Green Infrastructure. Land 2020, 9, 252. [CrossRef]

32. Khoshkar, S.; Hammer, M.; Borgström, S.; Balfors, B. Ways Forward for Advancing Ecosystem Services in Municipal PlanningExperiences from Stockholm County. Land 2020, 9, 296. [CrossRef]

33. Rędzińska, K.; Piotrkowska, M. Urban Planning and Design for Building Neighborhood Resilience to Climate Change. Land 2020, 9, 387. [CrossRef]

34. Elderbrock, E.; Enright, C.; Lynch, K.A.; Rempel, A.R. A Guide to Public Green Space Planning for Urban Ecosystem Services. Land 2020, 9, 391. [CrossRef]

35. Venvik, G.; Boogaard, F. Infiltration Capacity of Rain Gardens Using Full-Scale Test Method: Effect of Infiltration System on Groundwater Levels in Bergen, Norway. Land 2020, 9, 520. [CrossRef]

36. Restemeyer, B.; Boogaard, F.C. Potentials and Pitfalls of Mapping Nature-Based Solutions with the Online Citizen Science Platform ClimateScan. Land 2020, 10, 5. [CrossRef] 